\title{
Preoperative embolization of the splenic artery in patients that underwent splenectomy for immune thrombocytopenic purpura ${ }^{1}$
}

\author{
Embolização pré-operatória da artéria esplênica em pacientes submetidos à \\ esplenectomia por púrpura trombocitopênica immune
}

\author{
PlínioCarlos Baú ${ }^{2}$ Sílvio Adriano Cavazolla ${ }^{3}$, Hamilton Petry Souza ${ }^{4}$, Bernardo Garicochea ${ }^{5}$ \\ 1. Research performed at Post-Graduate Program, School of Medicine, Pontificial Catholic University of Rio Grande do Sul (PUCRS), Brazil. \\ 2. Associate Professor, Department of Surgery, PUCRS, Brazil. \\ 3. Interventionist Radiologist, São Lucas Hospital, PUCRS, Brazil. \\ 4. PhD, Associate Professor, Department of Surgery, PUCRS, Brazil. \\ 5. PhD, Associate Professor, Department of Oncology, PUCRS, Brazil.
}

\begin{abstract}
Transfusion of platelets, red blood cells, or both is usually necessary immediately after splenic artery ligature in patients with immune thrombocytopenic purpura who undergo splenectomy. Purpose: To investigate whether preoperative embolization of the splenic artery reduced the need for transfusion of platelets, red blood cells, or both. Methods: Twentyseven consecutive patients that underwent splenectomy for purpura between October 1999 and March 2006 performed by the same surgical team were enrolled. The first 17 patients did not undergo embolization and were compared with the next 10 patients, who composed the embolization group. Results: The platelet count in the embolization group rose from a mean $7000 \mathrm{u} / \mu 1$ before to $75000 \mathrm{u} / \mu 1$ after the procedure. There was no need for platelet or red blood cell transfusion in the embolization group; in the group without preoperative embolization, 11 patients $(p=0.001)$ required platelet transfusion and 8 ( $\mathrm{p}=0.01)$, red blood cell transfusion. Conclusion: Embolization of the splenic artery before splenectomy is a safe method to avoid blood transfusions in patients with ITP.
\end{abstract}

Key words: Purpura Thrombocytopenic, Idiopathic. Embolization, Therapeutic. Splenectomy.

\section{RESUMO}

A transfusão de plaquetas e ou hemácias geralmente é realizada em pacientes submetidos a esplenectomia por Purpura Trombocitopênia Imune (PTI). Objetivo: Investigar se a embolização pré-operatória da artéria esplênica é eficaz na redução da necessidade de transfusão de hemácias ou plaquetas. Métodos: Vinte e sete pacientes foram submetidos a esplenectomia por PTI de Outubro de 1999 a Março de 2006 pela mesma equipe cirúrgica. Os primeiros 17 pacientes não foram submetidos a embolização e foram comparados com os outros 10 individuos nos quais a embolização foi realizada. Resultados: A contagem de plaquetas no grupo em que a embolização foi realizada subiu de uma média de $7000 \mathrm{u} / \mu \mathrm{l}$ antes do procedimento, para $75000 \mathrm{u} / \mu 1$ após. Não foi necessário transfundir plaquetas ou glóbulos vermelhos no grupo submetido a embolização comparado com 11 pacientes com transfusão de plaquetas $(\mathrm{p}=0,001)$ e 8 pacientes com transfusão de hemácias $(\mathrm{p}=0,01)$ no grupo sem embolização pré-operatória .Conclusão: A embolização pré-operatória da artéria esplênica é um método seguro e eficaz para evitar o uso de transfusões em esplenectomias por PTI.

Descritores: Púrpura Trombocitopênica Idiopática. .Embolização Terapêutica. Esplenectomia. 


\section{Introduction}

The major complication of splenectomy is significant blood loss, which is explained by the peculiar blood supply and parenchymal fragility of the spleen. Studies of preoperative splenic artery embolization (PAE) in the early 1990s suggested that this procedure might reduce the risk of hemorrhage $\mathrm{e}^{1,2}$. The effect of PAE on blood loss seems to be independent of the surgical technique used or of whether the procedure is performed by laparoscopy or laparotomy ${ }^{3}$. PAE seems especially promising for patients with immune thrombocytopenic purpura (ITP) because many have low platelet counts at the time when splenectomy is indicated. The use of PAE before splenectomy for patients with ITP may reduce the need for pre- and transoperative platelet transfusions, which still are standard practices ${ }^{4}$. We investigated whether the use of PAE before splenectomy was associated with a reduced need of platelet or red blood transfusion in a series of patients with ITP compared with a historical group of patients that underwent splenectomy without PAE.

\section{Methods}

This controlled study enrolled a historical cohort of patients that underwent splenectomy for immune thrombocytopenic purpura between October 1999 and March 2006 in our institution. The study group comprised 10 patients that underwent preoperative splenic artery embolization (PAE) and whose mean age was 29 years (range 16 to 78). The control group consisted of a historical series of 17 patients that underwent splenectomy without PAE. The demographic characteristics of the two groups are shown in Table 1. Splenectomy was performed using laparoscopy in 6 patients of the study group (60\%) and 13 of the control group (76\%), and using laparotomy in the other patients of both groups. This study was approved by the Committee on Research Ethics of the hospital where it was conducted. Written informed consent was obtained from all participants.

\section{Embolization technique}

PAE was performed six to 12 hours before surgery. The technique ${ }^{5}$ consisted of puncture of the femoral artery with catheterization of the splenic artery by fluoroscopy and infusion of a vial of PVA particles 300-355 $\mu$ in diameter (Contour Emboli, Boston Scientific Cork Ltd, Ireland) added to $30 \mathrm{ml}$ of iodinated contrast. The quantity of PVA particles used in the procedure varied according to spleen volume. The procedure was classified as satisfactory whenever $60-70 \%$ of the parenchyma volume was embolized. The choice of laparoscopy or laparotomy was made according to spleen volume: laparotomy was used for spleens larger than $1000 \mathrm{ml}$, as evaluated by ultrasound. The need of preoperative transfusion of blood and blood products was defined according to the practical guidelines of the American Society of Anesthesiologists ${ }^{6}$. Red blood cells were transfused when hemoglobin level was below $6 \mathrm{~g} / \mathrm{dl}$. At levels between 6 and $10 \mathrm{~g} / \mathrm{dl}$, transfusion was indicated only in case of bleeding or when the patient was at risk of complications due to inadequate oxygen supply (low cardiopulmonary reserve or high oxygen consumption). Platelet transfusion was indicated when platelet count was below 50 X $10^{9} / \mathrm{L}$ or when bleeding occurred. Baseline clinical and laboratory data that might determine different postoperative outcomes were compared between the two groups. The Student T test was used to compare quantitative, normally distributed data. In case of asymmetry, the non-parametric Mann-Whitney test was used. Categorical variables were compared using chi-square and the Fisher exact tests because of the small sample size. The level of significance was set at $\alpha=0.05$, and data were analyzed using the SPSS 12.0 software.

\section{Results}

Clinical data and transfusion needs of the study and control groups are shown in Table 1. Demographic variables were similar in the two groups. No differences were found between laparoscopy or laparotomy and the need of transfusion $(p=0.17)$. The embolization group did not receive any red blood cell or platelet transfusions; in the group without PAE, eight patients received packed red blood cells $(p=0.01)$ and 11 , platelets $(p=0.001)$ (Figure 1). Patients that needed transfusion received a mean $3.2 \mathrm{U}$ red blood cells and a mean 9.2 U platelets. Platelet counts increased significantly in the embolization group (Figure 1). No deaths were observed in either group.

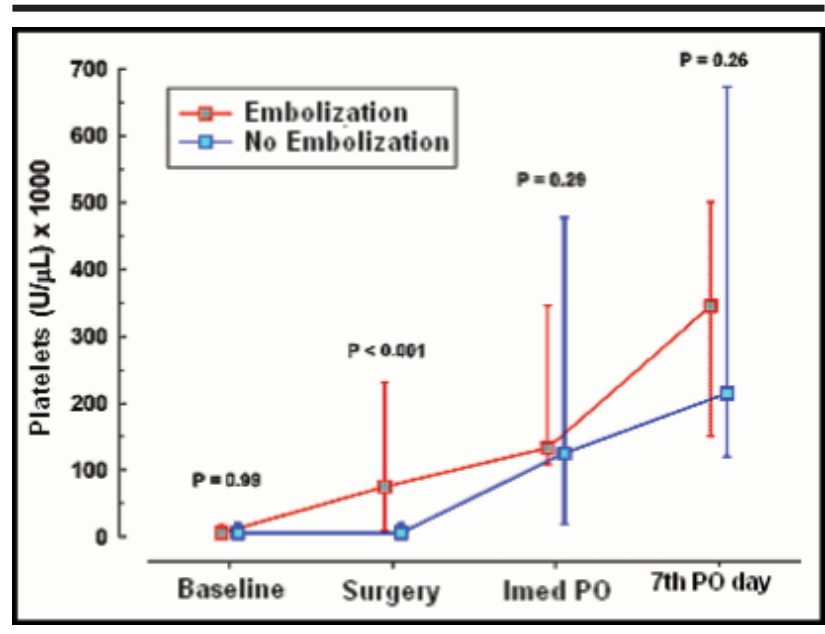

FIGURE 1 - Platelet counts 
TABLE 1 - Characteristics of patients that underwent splenectomy for immune thrombocytopenic purpura (ITP) with or without preoperative embolization of the splenic artery (PAE)

\begin{tabular}{|c|c|c|c|}
\hline & Study group (PAE) & Control group (no PAE) & \\
\hline Characteristics & $\mathrm{n}=10$ & $\mathrm{n}=17$ & $\mathrm{P}$ \\
\hline Age, years & 29 (16 to 78$)$ & 32 (11 to 52$)$ & 0.71 \\
\hline Female, N (\%) & $4(40)$ & $12(71)$ & 0.22 \\
\hline \multicolumn{4}{|l|}{ Platelets $(\mathrm{U} / \mu \mathrm{l}) \times 1000$} \\
\hline Baseline & $6(4$ to 17$)$ & $6(1$ to 20$)$ & 0.99 \\
\hline Surgery & $75(9$ to 231$)$ & $6(1$ to 20$)$ & $<0.001$ \\
\hline Immediately after operation & $133(109$ to 345$)$ & 125 (19 to 477$)$ & 0.29 \\
\hline 7th postoperative day & $345(151$ to 500$)$ & $215(120$ to 673$)$ & 0.26 \\
\hline Surgical technique, N (\%) & & & 0.17 \\
\hline Laparotomy & $4(40)$ & $4(24)$ & \\
\hline Laparoscopy & $6(60)$ & $13(76)$ & \\
\hline \multicolumn{4}{|l|}{ Need of transfusion, N (\%) } \\
\hline RBCU & $0(0)$ & $8(47)$ & 0.01 \\
\hline Platelets & $0(0)$ & $11(65)$ & 0.001 \\
\hline
\end{tabular}

Data are described as median (minimum to maximum) or frequency (percentage).

RBCU: packed adult red blood cells.

\section{Discussion}

The rates of mortality and morbidity associated with splenectomy have declined in the last two decades partly because of technical advances in surgical procedures. Videolaparoscopy and embolization of the splenic artery are two of the most relevant developments in this area ${ }^{7}$. However, splenectomy is still regarded as a risk procedure, especially because of the usually critical clinical conditions that lead to it. The technical evolution of splenectomy was well established in a comprehensive metanalysis with almost 3000 patients, in which a significantly greater number of general complications was found in the open splenectomy (OS) group than in laparoscopic splenectomy (LS) group $(26 \% \text { vs. 16\%) })^{3}$. Despite such encouraging results, the separate analysis of hemorrhagic complications showed that there were no differences between the two surgical procedures. Studies with small series of patients with ITP who underwent splenectomy using LS or who received PAE reported conflicting results ${ }^{1,2}$. Several patients required conversion from LS to OS in one study ${ }^{2}$ despite the use of PAE, which raises the question of whether PAE and LS should be reserved exclusively for a subgroup of patients with smaller spleens and better clinical conditions. Blood transfusions carry the risk of triggering immune responses, particularly due to immunosuppression and proinflammatory effects, which may lead to acute lung injury, as well as the risk of infections, such as HIV, hepatitis and syphilis. In this study, all patients underwent splenectomy because of clinically refractory ITP, and all had, as expected, normal-sized or slightly enlarged spleens.
In the group in which PAE was not performed, hemorrhagic complications were severe enough to require transfusions of platelets in $65 \%$ and of red blood cells in $47 \%$ of the cases. In the group that underwent PAE, blood transfusions were not necessary. The PAE technique has been offered to almost all our patients since it became available in our institution in 1999. In this study, there was no selection of patients according to clinical data or platelet counts, and our results are even more compelling because the study patients had thrombocytopenia. Previous PAE studies enrolled splenectomized patients with hematological and non-hematological disorders, and reported that PAE seemed to be the most important factor in avoiding transfusion. Moreover, PAE, which precludes the use of blood products, was beneficial to both OS and LS patients. Our review of the literature did not yield any studies with a sample of patients as large as the one in our series. Our study compared study and control groups in an attempt to reach a definitive conclusion about the advantages of PAE. The studies published so far, such as the one conducted by Poulin et al. ${ }^{2}$, enrolled patients that underwent splenectomy due to several pathologies, and not due to a specific disease such as ITP. Other studies were case reports of selected patients ${ }^{4}$. One of the limitations of our study was the relatively small number of patients in the study group, as ITP is a rare pathology usually treated clinically in our institution. This also explains why a historical series was used to compose the control group. 


\section{Conclusion}

The results seem to confirm the advantages of preoperative embolization of the splenic artery for patients that undergo splenectomy for ITP when compared with patients without PAE. This embolization technique is safe and not associated with postoperative morbidity because of advances in radiological procedures. The use of PAE seems to be a great advance in the surgical treatment of ITP as it prevents blood transfusions regardless of which surgical technique is used.

\section{References}

1. Totte E, Van Hee R, Kloeck I, Hendrickx L, Zachee P, Bracke P, Hermans P. Laparoscopic splenectomy after arterial embolization. Hepatogastroenterology. 1998;45:773-6.

2. Poulin E, Thibault C, Mamazza J, Girotti M, Côté G, Renaud A. Laparoscopic splenectomy: clinical experience of preoperative splenic artery embolization. Surg Laparosc Endosc. 1993;3(6):445-50.

3. Winslow ER, Brunt MB. Perioperative outcomes of laparoscopic versus open splenectomy: A metaanalysis with an emphasis on complications. Surgery. 2003;134(4):647-55.

4. Bahini, A, Hannoun, L, Parc, R. Embolisation Pré-Opératoire de L'Artère Splénique. Ann Chir. 1986;40(3):201-4.

5. Spigos CL, Boxt LM, Bettman MA. Partial splenic embolization in treatment of hypersplenism. Am J Roentegenol. 1979;132:777-82.

6. Practiceguidelinesforperioperativebloodtransfusionand adjuvant therapies. Anesthesiology. 2006;105:198-208

7. Cordera F, Long KH, Nagorney DM, McMurtry EK, Schleck C, Ilstrup D, Donohue JH. Open versus laparoscopic splenectomy for idiopathic thrombocytopenic purpura: clinical and economic analysis. Surgery. 2003;134(1):45-52.

\section{Correspondence:}

Plínio Carlos Baú

Av Ipiranga, 6690/506

90610-000 Porto Alegre - RS - Brazil

pliniobau@,via-rs.net
Conflict of interest: none Financial source: none

Received: April 18, 2007

Review: June 20, 2007

Accepted: July 19, 2007

\section{How to cite this article}

Baú PC, Cavazolla AS, Souza HP, Garicochea B. Preoperative embolization of the splenic artery in patients that underwent splenectomy for immune thrombocytopenic purpura. Acta Cir Bras. [serial on the Internet] 2007 Nov-Dec;22(6). Available from URL: $\underline{\text { http://www.scielo.br/acb }}$ 